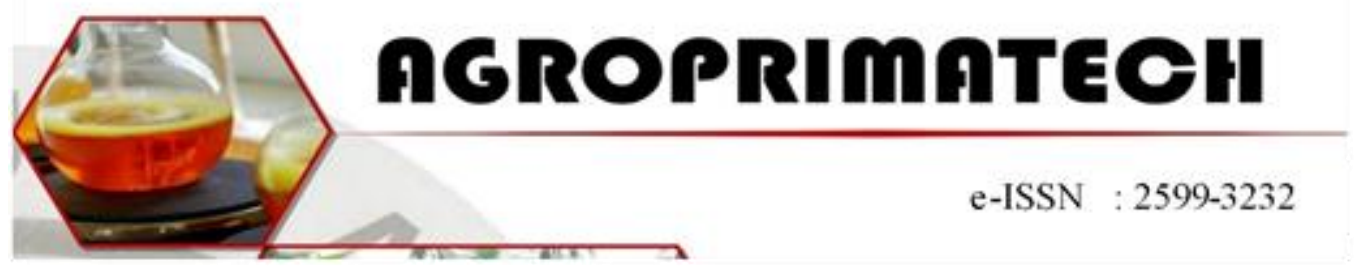

\title{
INVENTARISASI SERANGGA MALAM (NOCTURNAL) PADA LAHAN KONVERSI TEH MENJADI KELAPA SAWIT
}

\author{
JULAILI IRNI ${ }^{1}$, SARI ANGGRAINI ${ }^{2}$, SHELLA RENDAWA ${ }^{3}$ \\ 1,2 Dosen Fakultas Agro Teknologi, Universitas Prima Indonesia \\ ${ }^{3}$ MahasiswaFakultas Agro Teknologi, Universitas Prima Indonesia \\ Email: julailiirni@yahoo.com
}

\begin{abstract}
ABSTRAK
Penelitian ini bertujuan untuk mengetahui keanekargaman serangga malam yang ada di lahan konversi Teh menjadi kelapa sawit, apakah populasi serangga yang berada di lahan konversi Teh menjadi Kelapa sawit menimbulkan penambahan spesies atau bahkan spesies tersebut migran atau bahkan punah.

Metode yang di pakai dalam penelitian ini jebakan/trapping dengan teknik purposive sampling dalam meletakkan jebakan untuk memperoleh data seranggga malam hari yang di butuhkan. Berdasarkan hasil dan pembahasan, dapat disimpulkan sebagai berikut: 1 . Ditemukan 1475 individu serangga nocturnal yang tergolong dalam 9 genus, 9 Famili dan 8 Ordo yang terdapat pada lahan konversi teh menjadi kelapa sawit .3 Indeks keanekaragaman ( $\mathrm{H}^{\prime}$ ) serangga Nocturnal pada perkebunan kelapa sawit yang ditemukan pada stasiun 1-15 sebesar -0.96. kemudian Indeks kemerataan (E') serangga pada stasiun 1-15 sebesar 0.30, indeks kekayaan (Dmg) serangga pada stasiun 1-15 sebesar 2.53.
\end{abstract}

Kata Kunci: Inventarisasi, Serangga, Konversi, Kelapa Sawit

\section{PENDAHULUAN}

Serangga sebagai salah satu organisme dengan keanekaragaman yang tinggi merupakan kekayaan hayati Indonesia yang diperhatikan keberadaannya .Jumlah serangga mencapai sekitar 250.000 jenis atau $15 \%$ dari biota yang ada di Indonesia (Borror, 1996). Serangga adalah anggota dari filum atropoda (binatang dengan kaki beruas-ruas) yang terbagi menjadi tiga sub filum yaitu filum Trilobita (telahpunah dan tinggal sisa-sisanya/fosil) Chelicerata (terdiri atas beberapa kelas termasuk Arachnida) dan Mandibulata (terdiri atas beberapa kelas yang salahsatunya adalah kelas insect/Hexapoda).

Penggolongan jenis serangga berdasarkan aktivitasnya, dikenal serangga yang aktif disiang hari (Diurnal) dan serangga yang aktif dimalam hari
(Nocturnal). Serangga malamhari (Nocturnal) adalah hewan yang tidur pada siang hari, dan aktif pada malam hari. Serangga Nocturnal umumnya memiliki kemampuan penglihatan yang tajam.Serangga Nocturnal dapat melihatgelombang cahaya yang lebih panjang daripada manusia dan dapat memilah panjang gelombang cahaya yang berbeda-beda. Panjang gelombang cahaya dari 300-400 nm (mendekati ultraviolet) sampai 600-650 nm (orange). Diduga bahwa serangga tertarik pada ultraviolet karena cahaya itu merupakan cahaya yang diabsorbsi oleh alam terutama oleh daun (Borror, 1996). Konversi hutan menjadi lahan pertanian, tidak saja menyebabkan kerusakan vegetasi penyusun hutan tersebut, tetapi juga berpengaruh negatif terhadap serangga yang berasosiasi 
dengannya. Sejumlah kelompok serangga seperti kumbang pupuk, semut, kupu-kupu dan rayap memberikan respon yang khas pada tingkat kerusakan sehingga memilih potensi sebagai spesies indikator untuk mendeteksi perubahan lingkungan terhadap konversi hutan oleh manusia yang sekaligus menjadi indikator kesehatan hutan. Indonesia menghadapi situasi penurunan produksi dan kualitas tehnya. Saat ini produksi teh dalam negri hanya 120 ribu ton setahun, jumlanya anjlok dibandingkan produksi teh dalam negri 7 tahun lalu yang bisa menembus 160 ribu ton. Seperti yang terjadi pada PT. Perkebunan Nusantara IV Marjandi dan Bah birong hulu, melakukan konversi lahan tanaman teh yang dinilai sudah tidak bisa memberi keuntungan lagi terhadap perusahaan dan mengganti menjadi tanaman kelapa sawit yang di nilai sangat bernilai bisnis dan memberikan banyak keuntungan bagi perusahaan serta memiliki prospek yang cerah sebagai sumber devisa.

\section{METODE PENELITIAN}

Penelitian ini dilaksanakan pada bulan juli 2019. Pengambilan sampel dilakukan di perkebunan Bah Birong Hulu Jorlang hataran, Kabupaten Simalungun, Sumatera utara. Alat yang digunakan dalam penelitian ini adalah : modifikasi Light Trap dan yellow trap, Saringan, kamera, detergen, alat tulis, tabel pengamatan, botol sampel.

Bahan-bahan yang digunakan pada penelitian ini adalah: Buku identifikasi pelajaran Pengenalan serangga. Buku identifikasi Australian beetles (Lawrence dan Britton 1994). Pengambilan sampel dan data dilakukan dengan menggunakan perangkap modifikasih light trap danyellow trap dan line transek, penentuan titik trap berdasarkan/menggunakan teknik purposive dan pengambilan data berdasarkan/meggunakan line transek. Luas areal yang dijadikan pengambilan sampling 2,5 ha dan stasiun penempatan trap sebanyak 15 titik.

Pengambilan sampel lahan seluas 2,5 ha. Dengan pengambilan titik sampel 5 titik dengan garis line transek 500 meter dari sisi depan, belakang, samping kiri, samping kanan, dan tengah, disetiap titik di letakkan 3 light trap dan yellow trap, dilakukan berulang selama 3 hari lamannya.

\subsubsection{Penentuan lokasi pengamatan}

Sebelum melakukan pengamatan terlebih dahulu dilakukan survei lapangan untuk mengamati secara langsung kondisi lapangan sesuai kebutuhan penelitian.Hal ini dilakukan untuk memudahkan peneliti dalam menepatkan tempat dari lokasi pengamatan.Survei dilakukan pada beberapa lahan konversi tersebut.Pengumpulan data dilakukan dengan menggunakan perangkap modifikasiLight Trap dan yellow trap.

a. Suhu

Suhu udara diukur pada tempat pemasangan perangkap dengan mengunakan Thermohigrometer yaitu dengan cara menekan tombol restart kemudian membiarkan selama \pm 5 menit dan membaca skalanya. Pengukuran dilakukan pada jam 20:00 wib.

b. Kelembaban

Pengukuran kelembaban di tempat perangkap dilakukan dengan menggunakan Thermohigrometer yaitu dengan cara menekan tombol restart kemudian membiarkan \pm 5 menit dan membaca skalanya. Pengukuran dilakukan pada pukul 20.00-22.00 wib dan pengambilan kedua pada pukul 23.00-01.00 wib.

\subsection{Analisis Data}

Analisis data dilakukan secara desktriptif dan kualitatif. Analisi desktiptif dan kualitatif mengunakan analisis ini untuk mendekripsikan kondisi lingkungan dan berkaitan dengan kehadiran serangga, selain itu juga digunakan untuk menjelaskan pemanfaatan keanekaragaman serangga nocturnal di kawasan PTPN IV Bah Birong Ulu, hasil untuk mengetahui keanekaragaman serangga nocturnal di 
kawasan PTPN IV Bah Birong Ulu. Analisis data indeks menggunakan formula.

\subsubsection{Indeks Keanekaragaman Shanoon winner}

Keanekaragaman

merupakan ciri tingkatan

berdasarkan organism

Keanekaragaman spesies dapat digunakan untuk menyaktakan struktur komunitas, yaitu kemampuan suatu komunitas untuk menjaga dirinya tetap stabil meskipun ada gangguan terhadap komponen komponennya (Soegianto, 1994 dalam Indriyanto, 2006) Untuk mengetahui keanekaragaman jenis dihitung dengan menggunakan indeks keanekaragaman Shanon-Winner (Odum, 1993), dengan rumus sebagai berikut:Keterangan

$\mathrm{H}^{\prime}=$ Indeks keanekaragaman ShannonWinnner

$\mathrm{ni}=$ Jumlah individu jenis ke-i

$\mathrm{N}=$ jumlah individu seluruh jenis

Kriteria nilai indeks keanekaragaman Shanon-winner $\left(\mathrm{H}^{\prime}\right)$ adalah sebagai berikut : $\mathrm{H}=-\sum$ pi In pi

Dimana $\mathrm{H}$ = indeks keanekaragaman

$\mathrm{Pi}=$ nilai penting

Kriteria Indeks keanekaragaman Shannon-

Wiener dibagi menjadi 3 yaitu:

$\mathrm{H}<1$ = Keanekaragaman Rendah

$1<\mathrm{H}<3$ = Keanekaragaman Sedang

$\mathrm{H}>3$ = Keanekaragaman Tinggi 3

\subsubsection{Indeks kemerataan Eveness}

Nilai indeks kesamarataan jenis

dapat menggambarkan kestabilan suatu komunitas.Nilai indeks kemerataan (E) berkisar antara 0-1. Semakin kecil nilai $E$ atau mendekati nol, maka semakin tidak merata penyebaran organisme dalam komunitas tersebut yang didominasi oleh jenis tertentu dan sebaliknya semakin besar nilai $\mathrm{E}$ atau mendekati satu, maka orgaisme dalam komunitas akan menyebarsecara merata.Untuk megetahui besarnya indeks kesamarataan menurut (Pielou, 1966 dalam Odum,1993), sebagai berikut:

Rumus: $E 1={ }^{\prime} H: \max =H:{ }^{\prime} \ln (S)=$ $\ln (N 1) \ln (N 0$

Keterangan:

$$
\begin{aligned}
& \mathrm{e}^{\prime}=\text { Indeks kemerataan jenis } \\
& \mathrm{H}^{\prime}=\text { Indek Shannon } \\
& \mathrm{Si}=\text { Jumlah jenis yang ditemukan } \\
& \mathrm{Ln}=\text { Logaritma natural }
\end{aligned}
$$

Nilai indeks kemerataan berkisar antara 0-1. Apabila nilai $\mathrm{E}<0,20$ dapat dikatakan kondisi penyebaran jenis tidak stabil, sedangkan apabila nilai $\mathrm{E} 0,21 \leq \mathrm{E} \leq 1$ dapat dikatakan kondisi penyebaran jeis stabil (krebs, 1986)

\subsubsection{Indeks kekayaan Margalef}

Indeks kekayaan ini menunjukan perbandingan banyaknya satu spesies terhadap jumlah seluruh spesies.Dan menunjukkan perbandingan banyaknya satu spesies terhadap jumlah seluruh spesies.Indeks kekayaan Margalef di rumuskan sebagai berikut:

Rumus: DMg (Margalef) $=\frac{S-1}{\boldsymbol{i n N}}$

Keterangan:

$\mathrm{N}$ : Total individu dari seluruh spesies yangtercatat,

$S$ : Banyaknya spesies

Berdasarkan hasil analisis, terdapat dua kecenderungan yang dihasilkan dari pertambahan $\mathrm{S}$ dan $\mathrm{N}$ di dalam penggunaan Indeks Margalef, yaitu sebagai berikut: Nilai indeks diversitas Margalef akan meningkat apabila nilai $\mathrm{N}$ (jumlah total individu yang teramati) semakin bertambah, disertai dengan pertambahan nilai $S$ (jumlah jenisyang teramati).

Dmg $<3,5$ maka kekayaan jenis rendah

$3,5<$ Dmg $<5$ maka kekayaan jenis sedang

-Dmg > 5 maka kekayaan jenis tinggi

Jika mengacu pada panjang selang yang tidak sama dari kategori tersebut maka dapat dikatakan bahwa indeks diversitas Margalef tidak cukup peka dalam menilai kekayaan jenis. Penilaian terhadap tingkat kekayaan jenis yang rendah memiliki selang yang pendek. Sementara itu, tingkat kekayaan tinggi memiliki jarak selang yang lebih panjang sehingga kategori kekayaan jenis yang tinggi sangat lebih memungkinkan diperoleh dibandingkan kategori sedang dan rendah. 


\section{HASIL DAN PEMBAHASAN}

Tabel 1. Indeks Keanekaragaman (H') Kemerataan (E) Dan Kekayaan (Dmg) Jenis Serangga Nocturnal Pada Perkebunan Kelapa Sawit Bah Birong Ulu

\begin{tabular}{lcc}
\hline & Nama Ordo & Jumlah individu \\
1 & Isoptera & 715 \\
2 & Lepidoptera & 217 \\
3 & Coleoptera & 59 \\
4 & Diptera & 236 \\
5 & Orthoptera & 79 \\
6 & Orthoptera & 29 \\
7 & Formicidae & 63 \\
8 & Hymenoptera & 56 \\
9 & Gryllotalpidae & 21 \\
& total Individu & 1475 \\
\hline
\end{tabular}

\begin{tabular}{ccc}
\hline $\begin{array}{c}\text { Nilai indeks Shanoon } \\
\text { Winner }\end{array}$ & Nilai Indeks Margalef & Nilai Indeks Evennes \\
\hline 0.96 & 0.30 & 2.53 \\
\hline
\end{tabular}

Hasil perhitungan
keanekaragaman, $\begin{array}{r}\text { indeks } \\ \text { kemerataan dan }\end{array}$
kekayaan diperoleh histogram indeks
keanekaragaman dan kemerataan jenis
serangga nokturnal pada perkebunan kelapa
sawit disajikan pada Tabel tersebut, tiga
kriteria nilai indeks keanekaragaman jenis
yaitu, bila $H^{\prime}<1$ berartikeanekaragaman
tergolong rendah, bila $H^{\prime}=1-3$ berarti
keanekaragaman tergolong sedang, bila $H^{\prime}$ $>3$ berarti keanekaragaman tergolong tinggi.

Berdasarkan kriteria tersebut maka indeks keanekaragaman jenis serangga padaperkebunan kelapa sawit yang ditemukan pada setiap stasiun tergolong kategori sedang (1-3).Indeks keanekaragaman ini ditentukan oleh jumlah jenis dan distribusi kelimpahan tiap jenis serangga sehingga meskipun jumlah jenis individu serangga pada setiap stasiun berbeda namun indeks keanekaragamanpada stasiun 1-15 yaitu0.43.

Pada setiap stasiun tidak di bawah 1 dan di atas 3 sehingga dikategorikan sedang (Michael, 1995).Indeks keanekaragaman merupakan suatu penggambaran secara matematik untuk mempermudah dalam menganalisis informasi mengenai jumlah jenis indvidu serta berapa banyak jumlah jenis individu yang ada dalam suatu area.Dalam menilai potensi keanekaragaman hayati, seringkali keanekaragaman jenis menjadi pusat perhatian untuk diamati dibandingkan dengan keanekaragaman genetik (Odum, 1971).

Keanekaragaman yang tinggi menunjukkan bahwa suatu komunitas memiliki kompleksitas yang tinggi. Komunitas yang tua dan stabil akan mempunyai keanekaragaman jenis yang tinggi. Sedangkan suatu komunitas yang sedang berkembang pada tingkat suksesi mempunyai jumlah jenis rendah daripada komunitas yang sudah mencapai klimaks.Komunitas yang memiliki keanekaragaman yang tinggi lebih tidak mudah terganggu oleh pengaruh lingkungan. Jadi dalam suatu komunitas dimana keanekaragamannya tinggi akan terjadi interaksi spesies yang melibatkan transfer energi, predasi, kompetisi danniche yang lebih kompleks (Umar, 2013).Tiga 
kriteria komunitas lingkungan berdasarkan nilai kemerataan, yaitubila $E^{\prime}<0,50$ maka komunitas berada pada kondisi tertekan. Bila $0,50<E^{\prime} \leq 0,75$ maka komunitas berada dalam kondisi labil sedangkan 0,75< $\mathrm{E}^{\prime} \leq$ 1,00 makakomunitas berada dalam kondisi yang stabil. Nilai indeks kemerataan ( $\left.E^{\prime}\right)$ dapatmenggambarkan kestabilan suatu komunitas, semakin kecil nilai $E^{\prime}$ atau mendekati nol, maka semakin tidak merata penyebaran organisme dalam komunitas tersebut yang didominansi oleh jenis tertentu dan sebaliknya semakin besar nilai E' atau mendekati satu, maka organisme dalam komunitas akan menyebar secara merata (Krebs , 1978).

\section{Indeks Keanekaragaman (Shanoon Winner)}

Nilai indeks Keanekaragaman yaitu 0.96 kategori rendah.Semakin kecil jumlah spesies dan variasi jumlah individu tiap spesies maka keanekaragaman suatu ekosistem semakin kecil.Keadaan seperti ini dapat menyebabkan ketidakseimbangan ekosistem apabila terjadi gangguan atau tekanan dari lingkungan, yang berarti hanya jenis tertentu yang mampu bertahan hidup (Nugroho.,,et.al 2015).

\section{Indeks Kemerataan (Evennes)}

Nilai indeks kemerataan jenis yaitu 0.30 kategori semakin buruk.Indeks kemerataan menunjukan derajat kemerataan kelimpahan individu antara setiap spesies. Apabila setiap jenis memiliki jumlah individu yang sama, makakomunitas tersebut mempunyai nilai Evenness maksimum. Sebaliknya, jika kemerataan kecil, maka dalam komunitas tersebut terdapat jenis dominan, subdominan dan jenis yang terdominasi, maka komunitas itu memiliki Evenness minimum. Nilai kemerataan memiliki rentang antara 0-1 jika nilai indeks yang diperoleh mendekati 1 berarti penyebarannya semakin merata (Ismaini,dkk.,2015).

\begin{tabular}{lrrrr}
\hline Kriteria & Tinggi & Sedang & Rendah & Hasil \\
\hline Indeks keanekaragaman & $H^{\prime}>3$ & $H^{\prime}<3$ & $H^{\prime}<1$ & $H^{\prime} 0,96$ \\
\hline
\end{tabular}

\begin{tabular}{lcccc}
\hline Kriteria & Tinggi & Sedang & Rendah & Hasil kemerataan \\
\hline Indeks keanekaragaman & 0,80 & 0,60 & 0,41 & 0.30 \\
\hline
\end{tabular}

\section{Indeks Kemerataan (Margalef)}

Semakin banyak jumlah jenis yang ditemukan maka indeks kekayaan juga semakin besar.Indeks kekayaan Margalef membagi jumlah spesies dengan fungsi logaritma natural yang mengindikasikan, bahwa pertambahan jumlah spesies berbanding terbalik dengan pertambahan jumlah individu. Hal ini juga menunjukan bahwa biasanya pada suatu komunitas yang memiliki banyak spesies akan memilki sedikit jumlah individunya pada setiap spesies (Ismaini, dkk.,2015).

\begin{tabular}{lcccc}
\hline Kriteria & Tinggi & Sedang & Rendah & Hasil kemerataan \\
\hline Indeks kemerataan & 0,80 & 0,60 & 0,41 & 2.53 \\
\hline
\end{tabular}

\section{Faktor Lingkungan}

\section{Suhu}

Suhu merupakan faktor lingkungan yang menemukan aktifitas hidup serangga. Pada suhu tertentu, aktivitas hidup serangga tinggi (sangat aktif), sedangkan pada suhu yang lain aktivitas serangga sangat rendah (kurang aktif). Rata-rata pengukuran suhu di lokasi pengamatan pada setiap stasiun pengamatan suhu udara relative sama, yaitu suhu udara stasiun 1-15 di hari pertama $16^{\circ} \mathrm{C}$, hari kedua di stasiun $1-15$ yaitu $24^{\circ} \mathrm{C}$ - 
$22^{\circ} \mathrm{C}$, dan dihari ketiga di stasiun 1-15 yaitu $24^{\circ} \mathrm{C}-22^{\circ} \mathrm{C}$. suhu tersebut masih berada dalam kisaran suhu untuk serangga berkembang dengan baik. Kisaran suhu yang efektif untuk hidup dan berkembang dengan baik adalah suhu minimum $15^{\circ} \mathrm{C}$, suhu optimum $25^{\circ} \mathrm{C}$ dan suhu maksimum $45^{\circ} \mathrm{C}$ (Jumar, 2000).

\section{Kelembaban}

Tempratur memberikan efek membatasi pertumbuhan organisme apabila keadaan kelembaban ekstrim tinggi atau rendah, akan tetapi kelembaban memberikan efek lebih kritis terhadap organisme pada kelembaban yang tinggi atau rendah. Banyak jenis serangga mempunyai batas toleransi sempit terhadap kelembaban. Jika kondisi kelembaban lingkungan sangat tinggi serangga dapat mati atau berimigran ke tempat lain. Kondisi yang kering kadangkadang juga mengurangi adanya jenis tertentu karena berkurangnya populasi (Odum, 1998). Rata-rata pengukuran kelembaban udara pada setiap stasiun pada perkebunan kelapa sawit cenderung sama, berkisaran $60 \%-75 \%$. Ukuran kelembaban masih dalam ukuran normal yaitu berkisaran $50 \%-90 \%$ yang masih dapat ditolerir oleh serangga untuk hidup dan berkembang biak pada tempat tersebut.

\section{KESIMPULAN}

Berdasarkan hasil dan pembahasan, dapat disimpulkan sebagai berikut: 1 . Ditemukan 1475 individu serangga nocturnal yang tergolong dalam 9 genus, 9 Famili dan 8 Ordo yang terdapat pada lahan konversi teh menjadi kelapa sawit . 2. Indeks keanekaragaman $\left(H^{\prime}\right)$ serangga nocturnal pada perkebunan kelapa sawit yang ditemukan pada stasiun 1-15 sebesar -0.96 . kemudian Indeks kemerataan (E') serangga pada stasiun 1-15 sebesar 0.30 , indeks kekayaan (Dmg) serangga pada stasiun 115 sebesar2.53.

Dari hasil pengamatan Inventarisasi serangga malam di lahan koversi teh menjadi kelapa sawit, serangga berjenis ordo Isoptera atau laron menjadi serangga yang paling mendominan. Selama tiga malam pengamatan terdapat 715 jumlah individu yang terperangkap di light/yellow Trap. Serangga malam dengan jenis ordo Grylloapidae atau orong-orong menjadi serangga yang nilai dominansi nya paling rendah mencapai 21 individu dengan pengamatan selama tiga malam.

\section{DAFTAR PUSTAKA}

ATI, 2000. Perkembangan Komoditi Teh Indonesia), Jakarta.

Borror, D.J., Triplehorn, C.A. dan N.F. Johson, 1996, Pengenalan Pelajaran Serangga Edisi ke-enam, Gadjah Mada University Press, Yogyakarta.

David Dent dan Anthony Young, 1981. Soil Survey and land Evaluation. Beorge Allen \& Unwim (Publisher) Itd. h. 115-127.

DirektoratJenderal Perkebunan. 2009. Statistik Perkebunan Indonesia 2008-2010 KelapaSawit. Direktorat Jenderal Perkebunan, DepartemenPertanian, Jakarta.

Djaenudin, D., Marwan H., Subagyo H., dan A. Hidayat. 2003. Petunjuk Teknis untuk Komoditas Pertanian.Edisi Pertama tahun 2003, ISBN 9799474-25-6. Balai Penelitian Tanah, Pusat Penelitian dan Pengembangan Tanah.

Lupita,Oktaviona, Agus Dharmawan, dan Sofia Ery Rahayu, 2016, Preferensi Serangga Nokturnal Terhadap Warna Lampu Light Trap Di Kebun Jeruk Siem" Malang: Universitas Negeri Malang.

Rosalyn, I., 2007, Indeks Keanekaragaman Jenis Serangga Pada Pertanaman Kelapa Sawit (Elaeis Guineensis Jacq,) Di Kebun Tanah Raja Perbaungan PT Perkebunan Nusantara III, USU Repository dan Agroklimat, Bogor. 
[PPKS] Pusat Penelitian Kelapa Sawit. 2012. Kelainan bibit kelapa sawit.[Internet]. [diunduh $2013 \mathrm{Nov}$ 13]. Tersedia pada:http://www.iopri.org.

Purba, Jan, E.C., 2009. Analisis FaktorFaktor Yang Mempengaruhi Alih fungsi Lahan

Tanaman Perkebunan Teh Menjadi Perkebunan Kelapa

Sawit Di Kabupaten Simalungun, Tesis Magister Ekonomi, Universitas Sumatera Utara.

Silitonga, P.H., 1973. Peta Geologi Lembar Bandung, Jawa, Ska 1:100.000. Direktorat Geologi, Bandung.

Soil Survey Division Staff, 1993.Soil Survey Division Manual.Soil Conservation Service.U.S.Department Agriculture Handbook No.18.

Soil Survey Staff, 2010.Keys to Soil Taxonomy.U.S.Department of Agriculture, Natural Resources Conservation Services. Eleventh Edition. 2010.

Suheriyanto D, 2008, Ekologi Serangga, UIN Malang Press.
Suprihatini,R.2000. Selera Pasar Masyarakat Rusia. Infoteh No.2, Mei 1998,Jakarta.

Syahputra, E., Sarbino dan Dian, S. 2011.Weeds Assessment di Perkebunan Kelapa Sawit Lahan Gambut.Jurnal Perkebunan dan Lahan Tropika 1: 37- 42.

Untung K, 1996, Pengantar Pengelolaan Hama Terpadu, Universitas Gadjah MadaPress, Yogyakarta.2001, Pengantar Pengelolaan Hama Terpadu, UGM -Press, Yogyakarta.

Umar, R, 2013, Penuntun Praktikum Ekologi Umum, Universitas Hasanuddin, Makassar.

Widodo, I.T dan B. D. Dasanto. 2010. Estimasi Nilai Lingkungan Perkebunan Kelapa Sawit ditinjau dari Neraca Air Tanaman Kelapa Sawit (Studi Kasus: Perkebunan Kelapa Sawit Kabupaten Siak, Propinsi Riau). J.Agromet 24 (1): 23 32. 